Bull. Chem. Soc. Ethiop. 2017, 31(1), 115-126.

ISSN 1011-3924

(c) 2017 Chemical Society of Ethiopia and The Authors

Printed in Ethiopia

DOI: http://dx.doi.org/10.4314/bcse.v31i1.10

\title{
EFFECT OF BIOCIDES AND ANIONIC HOMOPOLYMERIC INHIBITORS ON THE PRECIPITATION BEHAVIOR OF CALCIUM FLUORIDE
}

\author{
Afrasiab Ur Rehman ${ }^{1}$, Abbas Khan ${ }^{2 *}$, Muhammad Humayun ${ }^{1}$, Gulnaz Bibi ${ }^{3}$, Keying Shi $^{1}$ and \\ Fazal Raziq ${ }^{1}$ \\ ${ }^{1}$ Key Laboratory of Functional Inorganic Material Chemistry, Ministry of Education, Key \\ Laboratory of Physical Chemistry, School of Chemistry and Material Science, Heilongjiang \\ University, Harbin, 150080, China \\ ${ }^{2}$ Department of Chemistry, Abdul Wali Khan University Mardan 23200, Pakistan \\ ${ }^{3}$ Biomaterials Research Center, Korea Institute of Science and Technology (KIST), Seoul 136- \\ 791, Korea
}

(Received April 5, 2016; revised May 26, 2017)

\begin{abstract}
This paper describes the effect of biocides and of the anionic homopolymeric inhibitors on the precipitation behavior of calcium fluoride $\left(\mathrm{CaF}_{2}\right)$.The efficiency of inhibitors in the presence and absence of biocides was calculated using the half-life $\left(\mathrm{t}_{1 / 2}\right)$ approach, where $50 \%$ of the concentration has been precipitated. Conductometric and X-ray diffraction (XRD) analysis have been performed for the calcium fluoride scale minerals using three polymeric inhibitors and three biocides, which are commonly used in industrial processes. The main aim of the study was to investigate the role of anionic homopolymerspoly(acrylic acid) PAA, and of the oxidizing and non-oxidizing biocides such as; sodium hypochlorite, gluteraldehyde, tris(hydroxymethyl) nitromethane). It was found that addition of low concentration $(1-10 \mathrm{mg} / \mathrm{L})$ of the polymers $(\mathrm{K}-752, \mathrm{~K}-732$ and $\mathrm{K}$ $702)$ have great inhibitory effect on the precipitation of calcium fluoride $\left(\mathrm{CaF}_{2}\right)$. Their inhibition efficiency was in the order, K-752 > K-732 $>$ K-702. The observed behaviour can be attributed to the effect of molecular weight of the polymer. The polymer having higher molecular weight shows weaker inhibiting ability. However, the oxidizing and non-oxidizing biocides have no appreciable effect on their performance and hence on the overall inhibition process.
\end{abstract}

KEY WORDS: Calcium fluoride, Precipitation, Inhibition, Homopolymeric inhibitors, Biocides

\section{INTRODUCTION}

The precipitation property of calcium fluoride $\left(\mathrm{CaF}_{2}\right)$ and its inhibition is of particular interest due to its wide range of applications in electronics, spectroscopy, laser, industrial and environmental precipitation processes $[1,2]$. Therefore, the study of precipitation behavior of $\mathrm{CaF}_{2}$ is not only the main focus of industrial technologists but also of the academic scientists. In the field of water treatment a variety of additives are incorporated into formulation to achieve certain desired performance objectives of the industrial water systems. Typical additives used include polyphosphates, organophophonates, poly(acrtylic acid), poly(maleic acid), and copolymers containing a variety of functional groups such as carboxyl, acrylamide, sulfonic acid, ester, etc., The main function of these additives in the formulation is to prevent the deposition of unwanted residues (i.e., mineral scales, corrosion products, biomass, suspended matter, etc.) on the surface of equipments.

The influence of polymeric and non-polymeric inhibitors on the precipitation and crystallization of alkaline earth metal fluorides has been reported by several investigators [3-5]. These studies reveal that these inhibitors, when present at low concentration, markedly influence the crystallization kinetics. In oral care applications, calcium fluoride plays a key role in the

*Corresponding author. E-mail: abbas053@gmail.com 
topical application of fluoride solution to tooth enamel, the hydroxyapaptie, (HAP), $\mathrm{Ca}_{5}\left(\mathrm{PO}_{4}\right)_{3} \mathrm{OH}$, (the main inorganic component of tooth enamel) is converted to fluoroapaptie, (FAP), $\mathrm{Ca}_{5}\left(\mathrm{PO}_{4}\right)_{3} \mathrm{OF}$, on the enamel surface resulting in a much more carrier resistant phase [6]. The high concentration of Fluoride ion, $\mathrm{CaF}_{2}$ forms at the tooth surface in addition to fluoroapitate (FAP). The inhibition of dental caries that results from the topical application of fluoride salts has been related to a surface coating of $\mathrm{CaF}_{2}$ on enamel which the mineral phase; hydroxyapatite (HAP), from dissolution [7]. Other theories stress the reduced solubility of fluoroapitate (FAP) in contact with the salivary fluoride [8,9]. A new model suggests that the $\mathrm{CaF}_{2}$ layer serves as a medium for transporting the reacting ion to the fluoroapitate (FAP) hydroxyapatite (HAP) interface [10]. Currently, a large variety of polymer-based additives are commercially available and they possess a wide range of physical and chemical properties, molecular weights and purity. For example, poly(acrylic acids) or PAAs produced by different manufacturers can have distinctly different properties. Thus, the selection of polymer should be based on technical/business need and customer requirements. Asia (especially Pakistan) and some other parts of world are basically a low fluoride country where $84 \%$ of all drinking water sources have less than the optimal $(0.7 \mathrm{mg} / \mathrm{L})$ level of fluoride in them. Water resources of 632 $(63.8 \%)$ locations had very low fluoride levels of below $0.3 \mathrm{mg} / \mathrm{L}$; while in $210(21.2 \%)$ locations this level ranged from low to near optimal, i.e. $0.3 \mathrm{mg} / \mathrm{L}$ to $0.69 \mathrm{mg} / \mathrm{L}$. Only 61 $(6.15 \%)$ locations had a range of $0.7 \mathrm{mg} / \mathrm{L}$ to $1.0 \mathrm{mg} / \mathrm{L}$, and $62(6.25 \%)$ location had this mineral in the range of $1.01 \mathrm{mg} / \mathrm{L}$ to $2.0 \mathrm{mg} / \mathrm{L} .11(1.1 \%)$ locations had fluoride in the range of $2.01 \mathrm{mg} / \mathrm{L}$ to $3.0 \mathrm{mg} / \mathrm{L}$ and $15(1.5 \%)$ had this level higher than $3 \mathrm{mg} / \mathrm{L}$, the severe affect of higher concentration of fluoride intake have been reported by several investigators [11-17].

The influence of phosphonates and poly(acrylic acid) has also been investigated, although these additives were effective $\mathrm{CaF}_{2}$ inhibitors, the phosphonates/polymer have a good effect in terms of inhibition $\mathrm{CaF}_{2}$ crystal growth and surface coating of $\mathrm{CaF}_{2}$ on enamel [18-21]. The influence of few polymeric and non-polymeric inhibitors on the crystallization of alkaline earth metal fluorides has been reported by using a seeded growth technique [22]. It is also seen that the inhibition of calcium fluoride crystallization by phytic acid, phosphonates, and benzene polycarboxylic acid markedly influence the crystallization kinetics [23].

The kinetics of calcium fluoride crystal growth in the presence of polymeric inhibitors of varying composition was studied using the constant composition technique and a surface adsorption mechanism [24-26]. The inhibitory effect was interpreted in terms of adsorption, following the Langmuir isotherm of poly(acrylic acid) ions at the active growth sites. The kinetic data also suggests that anionic polymers, cationic and non-ionic charged polymers are ineffective calcium fluoride inhibitors. The influence of phosphonate and poly(acrylic acid) were also recently investigated using the constant composition technique [27-31].

\section{EXPERIMENTAL}

\section{Materials and methods}

The polymers used were poly(acrylic acid) (GOOD-RITE K-702), poly(acrylic acid)(GOODRITE K-732) and poly(acrylic acid)(GOOD-RITE K-752) and the biocides used in this experiment were sodium hypochlorite, gluteraldehyde, tris(hydroxymethyl)nitromethane. The detail of polymers is given in Table 1. All the chemicals used were of analytical grade, and used without further purification. The polymers were purchased from Lubrizol (BF Good Rite), while biocides, calcium chloride and sodium fluoride from BDH. All solutions were prepared in deionized and doubly distilled water.

Traditionally, the performance of precipitation inhibitors to control calcium fluoride scale formation in the presence of soluble impurities has been studied [31-32]. However, the effect of various biocides and cationic flocculants on the performance of anionic polymeric and non- 
polymeric inhibitors has been mostly overlooked. The present study is concerned with the impact of biocide architecture on the performance of anionic charged homopolymeric inhibitors on the precipitation behavior of calcium fluoride in aqueous medium.

\section{Sample preparation and characterization}

The $\mathrm{CaF}_{2}$ precipitate (ppt) was prepared in supersaturated solution of calcium fluoride in aqueous medium and collected on $0.2 \mu \mathrm{m}$ filter paper by filtering the solution through Whatman No. 1 filter paper. The ppt was dried at room temperature in the absence of air, and then subjected to characterization by conductometery and XRD for further analysis. The conductance measurements for the formation of $\mathrm{CaF}_{2}$ ppt and under the effect of various additives were carried out with the help of a digital Jenway-4310 conductivity meter. The instrument has auto ranging from $1.0 \times 10^{-6}$ to $1.999 \times 10^{-5} \mathrm{~S} . \mathrm{m}^{-1}$ and temperature control accuracy of $\pm 0.5{ }^{\circ} \mathrm{C}$. The measuring cell was immersed in a water circulating bath (IRMECO I-2400 GmbH Germany) in order to hold a constant temperature. Prior to any measurement, calibration of the conductivity meter was made with $\mathrm{KCl}$ aqueous solution by using the normal concentration data keeping the cell constant 1.04. All experiments were performed at $25{ }^{\circ} \mathrm{C}$ in a plastic container containing known volume of water while keeping the total volume of supersaturated solution was $150 \mathrm{~mL}$. The calcium fluoride supersaturated solution was prepared by mixing about $30 \mathrm{~mL}$ of $0.01 \mathrm{M}$ $\mathrm{CaCl}_{2}$ solution with $60 \mathrm{~mL}$ of $0.01 \mathrm{M} \mathrm{NaF}$ solution. The kinetics of calcium fluoride precipitation from supersaturated solution was studied by following the decrease in fluoride ion concentration with fluoride ion sensitive electrode under continuous stirring during the course of experiments. For this purpose, a homemade experimental setup was used.

To inhibit the precipitation of $\mathrm{CaF}_{2}$, a known volume of stock solution of inhibitor (Table 1) was added to sample vials before the addition of stock solution of calcium chloride. The $\mathrm{pH}$ of $\mathrm{CaF}_{2}$ supersaturated solution was adjusted around 7-8. Precipitation of calcium fluoride in the supersaturated solution was measured by analyzing aliquots of filtrate $(0.2 \mu \mathrm{m}$ filter paper $)$ with XRD. All homopolymers and biocides solutions were prepared on as-active solids basis. The decrease in fluoride ion concentration during the precipitation experiments was recorded on the chart recorder.

Table 1. Summary of polymers and biocides used in this study.

\begin{tabular}{|lll|}
\hline Inhibitor & Structure & Acronym/designation \\
\hline $\begin{array}{l}\text { COOH } \\
\text { Poly(acrylic acid) }\end{array}$ & $-\left(\mathrm{CH}_{2}-\mathrm{CH}\right)_{\mathrm{n}}-$ & $\begin{array}{l}\text { PAA/GOOD-RITE K-702 } \\
\text { (MW }=345,000 \mathrm{~g} / \mathrm{mol})\end{array}$ \\
$\begin{array}{l}\mathrm{COOH} \\
\text { Poly(acrylic acid) }\end{array}$ & $-\left(\mathrm{CH}_{2}-\mathrm{CH}\right)_{\mathrm{n}}-$ & $\begin{array}{l}\text { PAA/GOOD-RITE K-732 } \\
\text { (MW }=6,000 \mathrm{~g} / \mathrm{mol})\end{array}$ \\
$\begin{array}{l}\text { COOH } \\
\text { Poly(acrylic acid) }\end{array}$ & $-\left(\mathrm{CH}_{2}-\mathrm{CH}\right)_{\mathrm{n}}-$ & $\begin{array}{l}\text { PAA/GOOD-RITE K-752 } \\
\text { (MW }=2,000 \mathrm{~g} / \mathrm{mol})\end{array}$ \\
\hline Biocides & $\mathrm{I}$ & \multicolumn{2}{l|}{} \\
\hline Oxidizing & Generic description & Chemical name \\
\hline Non-oxidizing & NaOCl & Sodium hypochlorite \\
\hline Non-oxidizing & Gluteraldehyde & Gluteraldehyde \\
\hline
\end{tabular}




\section{RESULTS AND DISCUSSION}

\section{Conductometery}

Precipitation of $\mathrm{CaF}_{2}$ in the absence of inhibitor. The process of dissolving an ionic solid into water to form an aqueous solution requires the ionization of the compound into separate ions. Following the solubility concept, the precipitation behavior of $\mathrm{CaF}_{2}$ can be well understood from the value of its solubility product $\left(\mathrm{K}_{\mathrm{sp}}\right)$ and ionization pattern. The solubility of $\mathrm{CaF}_{2}$ can be represented in the terms of a chemical equation. The calculated $\mathrm{K}_{\mathrm{sp}}$ value for $\mathrm{CaF}_{2}$ at $25{ }^{\circ} \mathrm{C}$ was $4.00 \times 10^{-11}$. By mixing about $30 \mathrm{~mL}$ of $0.01 \mathrm{M} \mathrm{CaCl}_{2}$ solution with $60 \mathrm{~mL}$ of $0.01 \mathrm{M} \mathrm{NaF}$ solution then the reaction occur can be;

$$
\begin{aligned}
& \mathrm{CaCl}_{2(\mathrm{aq})}+2 \mathrm{NaF}_{(\mathrm{aq})} \rightarrow \mathrm{CaF}_{2(\mathrm{ppt})}+2 \mathrm{NaCl}_{(\mathrm{aq})} \\
& \mathrm{CaF}_{2} \text { dissociates as; } \quad \mathrm{CaF}_{2(\mathrm{ppt})} \rightarrow \mathrm{Ca}^{2+}+2 \mathrm{~F}^{-}
\end{aligned}
$$

The value of quotient (Q) was found to be about $2.218 \times 10^{-5}$ at room temperature. Since $2.218 \mathrm{x}$ $10^{-5}>4.00 \times 10^{-11}\left(\mathrm{Q}>\mathrm{K}_{\mathrm{sp}}\right)$ in this case, therefore, precipitation can occur for the above reaction under neutral solution conditions and at ordinary temperature. The variation in the concentration of $\mathrm{F}^{-}$ions with passage of time can be seen from Figure 1. It can be observed that with increasing the time period, the $\mathrm{F}^{-}$ions concentration in solution gradually decreases from 0.0190 to $0.00474 \mathrm{~g} / \mathrm{L}$. This trend is an indication of precipitation. Figure 1 also shows that the reaction attains equilibrium at and/or after $8.5 \mathrm{~h}$. Consequently, the half life $\left(\mathrm{t}_{1 / 2}\right)$, the time period at which $50 \%$ of the concentration has been precipitated, is about $4.25 \mathrm{~h}$.

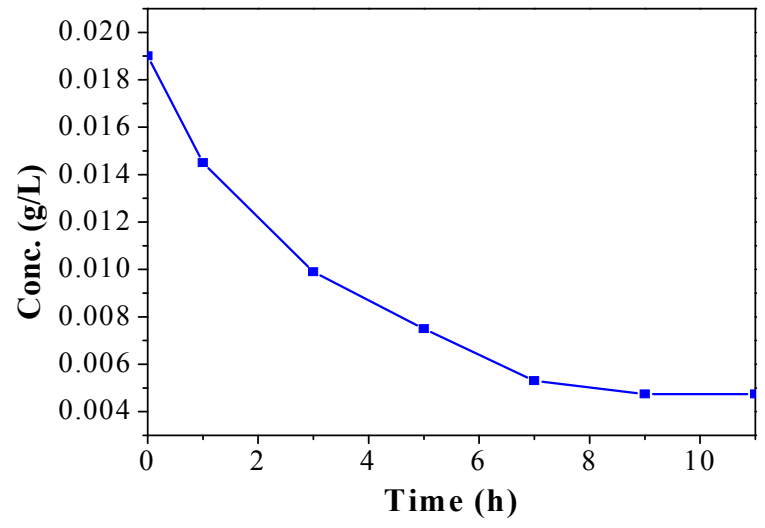

Figure 1. Variation in the concentration of $\mathrm{F}^{-}$ions with passage of time in the absence of inhibitor.

Precipitation of $\mathrm{CaF}_{2}$ in the presence of polymeric inhibitors. The influence of homopolymeric inhibitors on the precipitation of calcium fluorides has been studied by using three different acrylic acid based polymers which are coded as K-702, K-732 and K-752. The details of the homopolymeric inhibitors are given in Table 1 . Figure 2 shows the change in the concentration of $\mathrm{F}^{-}$ions as a function of time in the presence of different amount of K-702 inhibitor. The Figure shows that $\mathrm{F}^{-}$ions concentration gradually decreases with time down the group. The precipitation of $\mathrm{CaF}_{2}$ was clearly inhibited by the use of polymer K-702 from 1 to $10 \mathrm{mg} / \mathrm{L}$. The reaction reached to equilibrium at almost $11 \mathrm{~h}$ with a $\mathrm{t}_{1 / 2}$ of $5.5 \mathrm{~h}$ when the polymer K-702 with 
$1 \mathrm{mg} / \mathrm{L}$ was used, $13 \mathrm{~h}$ with $\mathrm{t}_{1 / 2}=6.5 \mathrm{~h}$ when $2 \mathrm{mg} / \mathrm{L}$ polymer was used, and $15 \mathrm{~h}$ with $\mathrm{t}_{1 / 2}$ of 7.5 $\mathrm{h}$ when $3 \mathrm{mg} / \mathrm{L}$ of polymer was added to the reaction mixture. Similarly, when $5 \mathrm{mg} / \mathrm{L}$ polymer was used in the mixture the equilibrium time was $17 \mathrm{~h}$ with a $t_{1 / 2}$ of $8.5 \mathrm{~h}$ while for $10 \mathrm{mg} / \mathrm{L}$ polymer the equilibrium time was $19 \mathrm{~h}$ with a $\mathrm{t}_{1 / 2}$ equal to $9.5 \mathrm{~h}$. It is important to mention that for the polymer free precipitation solution, the equilibrium time and $t_{1 / 2}$ was 8.5 and $4.25 \mathrm{~h}$, respectively. The results show that the precipitation is inhibited by addition of polymer and this inhibition ability of polymer further increases with increase in the amount of polymer from 1 to $10 \mathrm{mg} / \mathrm{L}$ in the reaction mixture. Comparing the $\mathrm{F}^{-}$ions concentration-time profile for $1 \mathrm{mg} / \mathrm{L}$ with that of $10 \mathrm{mg} / \mathrm{L}$ for $\mathrm{K}-702-\mathrm{CaF}_{2}$ mixed system, it can be seen that the concentration of $\mathrm{F}^{-}$ ions gradually increases 0.0049 to $0.01 \mathrm{~g} / \mathrm{L}$ in the solution. This again supports the view that more is the amount of polymer higher is its inhibiting efficiency.

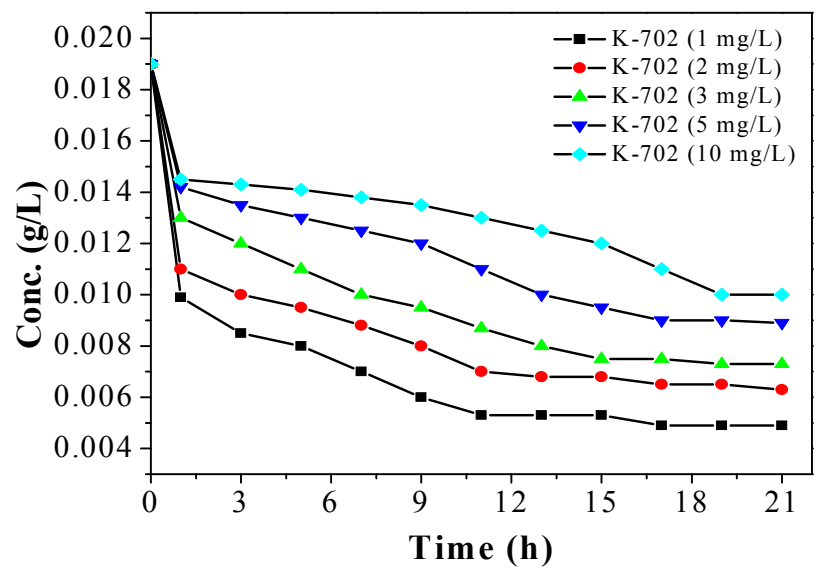

Figure 2. Variation in the concentration of $\mathrm{F}^{-}$ions with the passage of time in the presence of different amount of K-702 inhibitor.

In order to investigate the effect of the nature of the polymer on its inhibition ability, the precipitation behavior of $\mathrm{CaF}_{2}$ was also studied in the presence of different amount of K-732. Figure 3 represents the variation in the concentration of $\mathrm{F}^{-}$ions with the passage of time in the presence of different amount ( 1 to $10 \mathrm{mg} / \mathrm{L})$ of $\mathrm{K}-732$ inhibitor. It is evident that $\mathrm{F}^{-}$ concentration gradually decreases down the group with passage of time. Further, it is clear that the precipitation of $\mathrm{CaF}_{2}$ is also inhibited by the use of different amount of polymer K-732, and shows that $\mathrm{F}^{-}$concentration decreases down the group with time. Figure 3 shows that the time taken by the reaction to reach the equilibrium is varying with changing the amount of polymer. In other words the reaction reach to equilibrium condition at approximately $13 \mathrm{~h}$ with $\mathrm{t}_{1 / 2}=6.5$ $\mathrm{h}, 15 \mathrm{~h}$ with $\mathrm{t}_{1 / 2}=7.5 \mathrm{~h}, 17 \mathrm{~h}$ with $\mathrm{t}_{1 / 2}=8.5 \mathrm{~h}, 19 \mathrm{~h}$ with $\mathrm{t}_{1 / 2}=9.5 \mathrm{~h}$, and $21 \mathrm{~h}$ with $\mathrm{t}_{1 / 2}=10.5 \mathrm{~h}$ when the amount of polymer K-732 used was $1,2,3,5$, and $10 \mathrm{mg} / \mathrm{L}$, respectively. Thus, comparing these results with the equilibrium time of $8.5 \mathrm{~h}$ and $\mathrm{t}_{1 / 2}=4.25 \mathrm{~h}$ when no polymer was used, again reflecting the inhibition ability of polymer. Likewise, it can also be noticed that the inhibition power of K-732 further enhanced by increasing its ratio in the reaction mixture. Comparing the $\mathrm{F}^{-}$ions concentration-time profile for $1 \mathrm{mg} / \mathrm{L}$ with that of $10 \mathrm{mg} / \mathrm{L}$ of K-732, it can be seen that the concentration $\mathrm{F}^{-}$ions in the solution gradually increases 0.0068 to 0.0134 $\mathrm{g} / \mathrm{L}$. This supports the view that more is the amount of polymer higher is its inhibiting efficiency. 


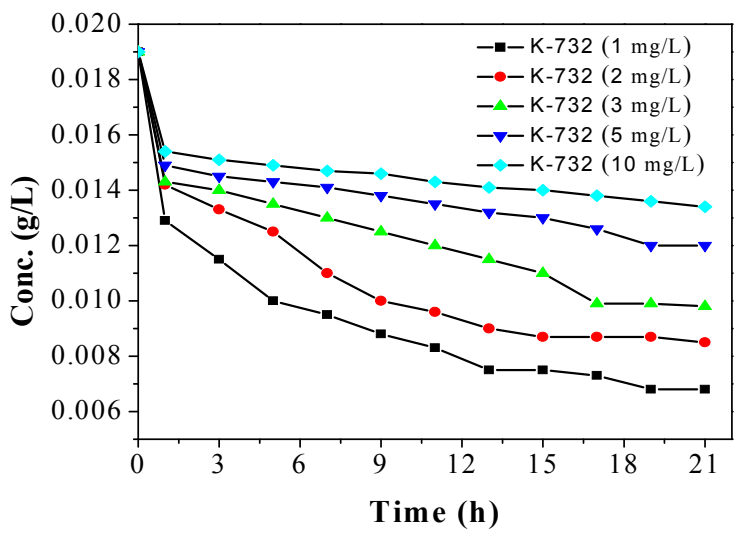

Figure 3. Variation in the concentration of $\mathrm{F}^{-}$ions with the passage of time in the presence of different amount of K-732 inhibitor.

To further highlight the effect of chemical nature of the polymeric inhibitor on $\mathrm{CaF}_{2}$ precipitation, a third polymer K-752 was also used in addition to the above mentioned polymers K-702 and K-732. Figure 4represents the variation in the concentration of $\mathrm{F}^{-}$ions with the passage of time in the presence of different amount ( 1 to $10 \mathrm{mg} / \mathrm{L})$ of $\mathrm{K}-752$ inhibitor. The precipitation of $\mathrm{CaF}_{2}$ was clearly inhibited by the use of polymer $\mathrm{K}-752$ from $1 \mathrm{mg} / \mathrm{L}$ to 10 $\mathrm{mg} / \mathrm{L}$ as $\mathrm{F}^{-}$concentration decreases down the group with time. Figure 4 shows that the reaction reached to equilibrium at approximately $15 \mathrm{~h}$ with $\mathrm{t}_{1 / 2}=7.5 \mathrm{~h}$ when polymer K-752 with $1 \mathrm{mg} / \mathrm{L}$ was used, $17 \mathrm{~h}$ with $\mathrm{t}_{1 / 2}=8.5 \mathrm{~h}$ when $2 \mathrm{mg} / \mathrm{L}$ was used, $19 \mathrm{~h}$ with $\mathrm{t}_{1 / 2}=9.5 \mathrm{~h}$ when $3 \mathrm{mg} / \mathrm{L}$ was used, and more than $21 \mathrm{~h}$ for both 5 and $10 \mathrm{mg} / \mathrm{L} \mathrm{K}-752$ was used. The trend shows that the inhibition ability of polymer increases gradually with increasing the amount of polymer from 1 to $10 \mathrm{mg} / \mathrm{L}$. The comparison of $\mathrm{F}^{-}$ions concentration-time profile for $1 \mathrm{mg} / \mathrm{L}$ with $10 \mathrm{mg} / \mathrm{L}$ of $\mathrm{K}-752$ clearly reflects that the concentration $\mathrm{F}^{-}$ions gradually increases from 0.0124 to $0.015 \mathrm{~g} / \mathrm{L}$ in the reaction mixture, showing that inhibiting efficiency of the polymeric inhibitor is linearly dependent on its amount.

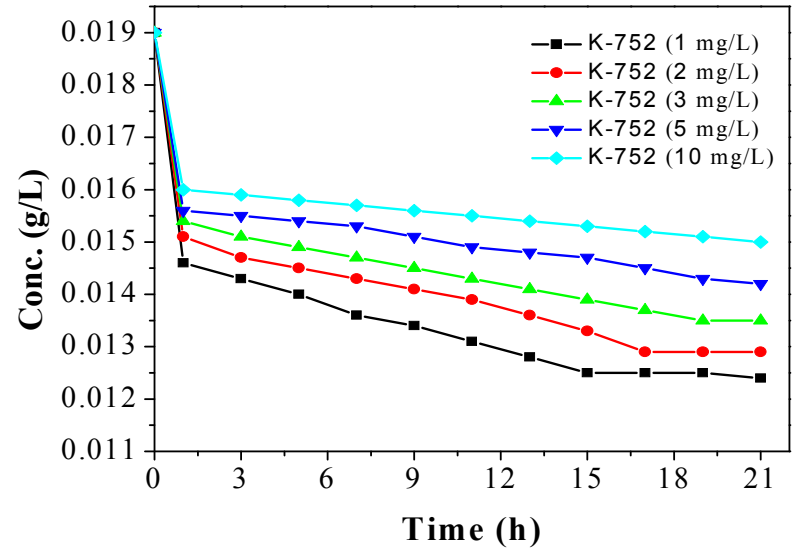

Figure 4. Variation in the concentration of $\mathrm{F}^{-}$ions with the passage of time in the presence of different amount of K-752 inhibitor.

Bull. Chem. Soc. Ethiop. 2017, 31(1) 
To summarize the effect of homopolymeric inhibitors, it can be said that all of these homopolymers (K-702, K-732 and K-752) significantly inhibit the precipitation processes of $\mathrm{CaF}_{2}$. This is reflected by increase in the life time of the precipitation equilibrium. It can further be seen that by increasing the amount of polymer from $1 \mathrm{mg} / \mathrm{L}$ to $10 \mathrm{mg} / \mathrm{L}$ in the reaction mixture, increase the overall efficiency of these ionic polymeric inhibitors. Similarly, the chemical nature of the inhibitor also plays a promising role in the precipitation inhibition. On the basis of results obtained, it can be said that K-702 and K-732 are weaker $\mathrm{CaF}_{2}$ precipitation inhibitors while the polymer K-752 shows better results. On the average, the inhibition power follows the order K-752 $>\mathrm{K}-732>\mathrm{K}-702$. This can be attributed to the effect of molecular weight of the polymer. Higher is molecular weight of the polymer lower is its inhibiting ability. This is because a polymer with larger molecular weight has weaker interaction with the solvent as compared to the one having lower molecular weight, and hence affecting the inhibition of $\mathrm{CaF}_{2}$ precipitation in a similar fashion. In addition, it can also be thought that the use of anionic homopolymeric inhibitors prominently affect the growth rate and morphology of the $\mathrm{CaF}_{2}$ precipitate, and the nature of the hydrated phase as well.

Effect of biocides on the precipitation of $\mathrm{CaF}_{2}$ in the presence of polymeric inhibitors. The effect of various concentrations of both oxidizing and non-oxidizing biocides on the precipitation behaviour of $\mathrm{CaF}_{2}$ in the presence of polymeric precipitation inhibitors was also studied in this project. Sodium hypochlorite $(\mathrm{NaOCl})$ was used as the oxidizing one while the non-oxidizing biocides includedgluteraldehyde, and trisnitromethane (tris-(hydroxymethyl)nitromethane). In addition to the chemical nature, the effect of the amount of biocides was also studied at two different concentrations i.e., $5 \mathrm{mg} / \mathrm{L}$ and $10 \mathrm{mg} / \mathrm{L}$. Figure 5 shows the change in the concentration of $\mathrm{F}^{-}$ions with time in the presence of $5 \mathrm{mg} / \mathrm{L}$ of K-702, K-732, K-752, and when $5 \mathrm{mg} / \mathrm{L}$ of sodium hypochlorite (an oxidizing biocide) was used. It can be observed that in the presence of $5 \mathrm{mg} / \mathrm{L}$ each of polymers (K-702, K-732, K-752) and sodium hypochlorite biocide, the $\mathrm{F}^{-}$concentration gradually increases from 0.0089 to 0.0122 and $0.0142 \mathrm{~g} / \mathrm{L}$. Further, the precipitation of $\mathrm{CaF}_{2}$ was found to be inhibited by the use of polymers such as $\mathrm{K}-702, \mathrm{~K}$ 732, and K-752 and sodium hypochlorite biocide with passage of time. However, a comparison of the biocide added system with the biocide free ones (Figures 2-4) shows that there found no appreciable effect on the performance of these polymeric inhibitors with the inclusion of biocide.

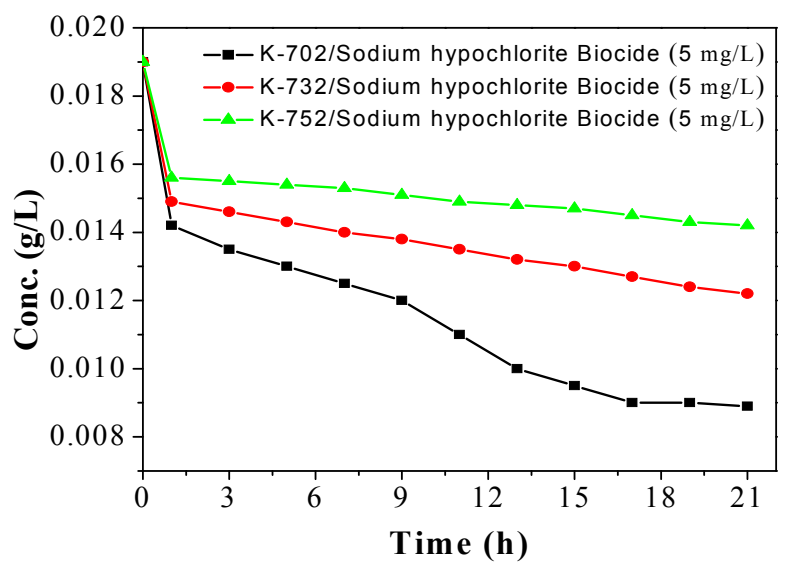

Figure 5. Variation in the concentration of $\mathrm{F}^{-}$ions with the passage of time in the presence of 5 $\mathrm{mg} / \mathrm{L}$ of K-702, K-732, K-752, and sodium hypochlorite biocide.

Bull. Chem. Soc. Ethiop. 2017, 31(1) 


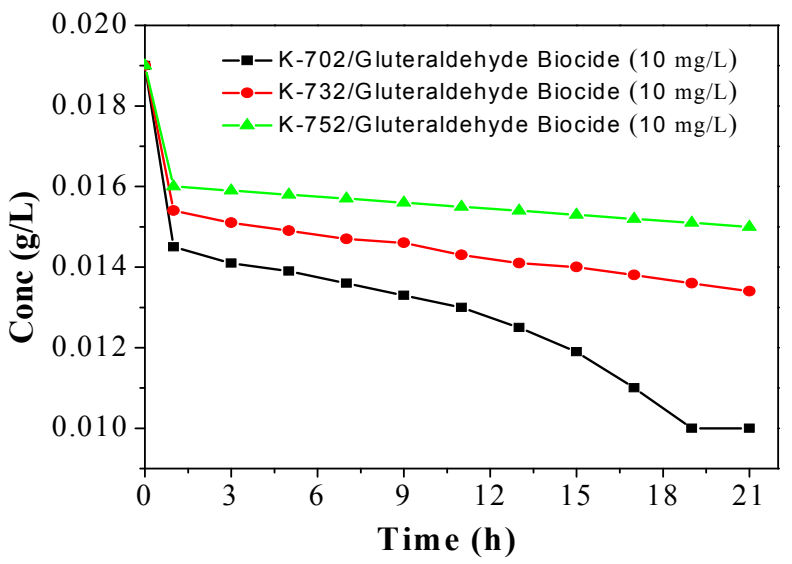

Figure 6. Variation in the concentration of $\mathrm{F}^{-}$ions with the passage of time in the presence of 10 $\mathrm{mg} / \mathrm{L}$ of $\mathrm{K}-702, \mathrm{~K}-732, \mathrm{~K}-752$ and gluteraldehyde biocide.

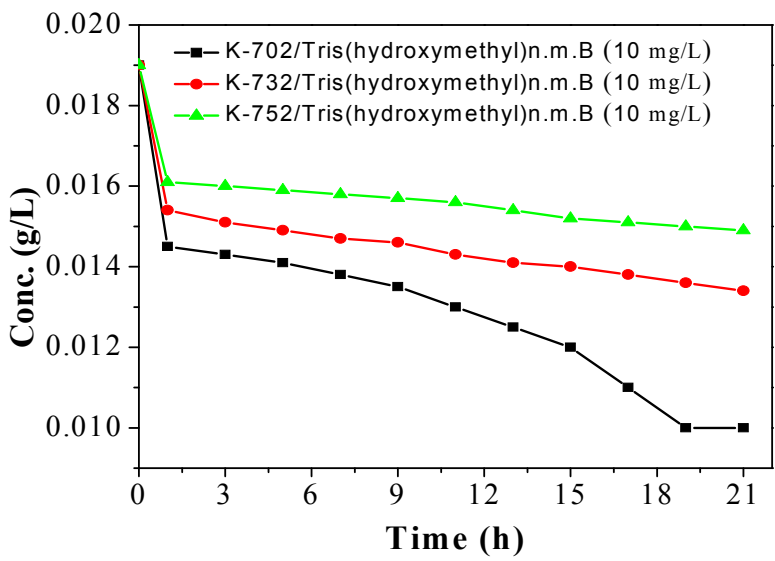

Figure 7. Variation in the concentration of $\mathrm{F}^{-}$ions with the passage of time in the presence of 10 $\mathrm{mg} / \mathrm{L}$ of K-702, K-732, K-752, and tris(hydroxymethyl)nitro methane biocide.

Further, to investigate the effect chemical nature of biocides on the precipitation of calcium fluoride in the presence of anionic homopolymeric inhibitors (K-702, K-732, K-752), the nonoxidizing biocides such as gluteraldehyde, and trisnitromethane (tris-(hydroxymethyl)nitromethane) were also used. The concentration of both non-oxidizing biocides used was kept at $10 \mathrm{mg} / \mathrm{L}$ each. Figure 6 shows the variation in the concentration of $\mathrm{F}^{-}$ions with the passage of time in the presence of $10 \mathrm{mg} / \mathrm{L}$ of K-702, K-732, and K-752, when gluteraldehyde biocide at $10 \mathrm{mg} / \mathrm{L}$ was used. It can be seen from Figure 6 that in the presence of $10 \mathrm{mg} / \mathrm{L}$ each of polymer and biocide the $\mathrm{F}^{-}$ions concentration gradually increases from 0.01 , to 0.0134 , and $0.015 \mathrm{~g} / \mathrm{L}$ for K-702, K-732, and K-752, respectively. It can be pointed out that gluteraldehyde biocide did not significantly affect the performance of inhibitors in comparison to biocide free systems. Likewise, to further highlight the effect of biocide another oxidizing biocide, the tris(hydroxymethyl)nitro methane, was also employed to the $\mathrm{CaF}_{2}$ solution containing polymer. 
The variation in the concentration of $\mathrm{F}^{-}$ions with the passage of time in the presence of $10 \mathrm{mg} / \mathrm{L}$ of K-702, K-732, K-752, and tris(hydroxymethyl)nitro methane biocide is indicated in Figure 7. It can be observed that $\mathrm{F}^{-}$concentration gradually increases from 0.011 to 0.0133 and 0.015 $\mathrm{g} / \mathrm{Lin}$ the presence of K-702, K-732, K-752, respectively, reflecting the inhibition property of polymers. However, a comparison to other biocides used, tris(hydroxymethyl)nitro methane also has no outstanding effect on the inhibition ability of these polymeric inhibitors. These results are in consistence with the earlier work related to the effects of biocides on deposit control polymers [32]. In simple words, we are of the view that that both the oxidizing as well as the non-oxidizing biocides demonstrate minor effect on the performance of these anionic homopolymeric inhibitors and hence on the overall precipitation process.

\section{$X$-Rays diffraction (XRD)}

In order to investigate the micro-structural and physicochemical properties of $\mathrm{CaF}_{2}$ precipitate, $\mathrm{X}$-Ray diffraction analysis were also performed. Structure analysis of the samples were carried out by using a PANalytical, (X'pertPRO, Netherlands) X-ray diffractometer (XRD). The main aim of the XRD analysis was to identify the presence of various chemical species in $\mathrm{CaF}_{2}$ precipitate in the absence and presence of polymeric inhibitors and biocides. Figure 8 represents the typical XRD patterns, taken after $21 \mathrm{~h}$ of precipitation process, of $\mathrm{CaF}_{2}$ precipitate in the absence and presence of homopolymeric inhibitors and biocides. The corresponding composition of the mixture used is also indicated on each spectrum. The various peaks observed in XRD spectra are assigned to various chemical constituents with the help of International Center for Diffraction Data (ICDD).

The spectrum at the bottom of Figure 8 is for $\mathrm{CaF}_{2}$ in the absence of both inhibitors and biocides. This XRD patterns for precipitation of $\mathrm{CaF}_{2}$ was taken after $9 \mathrm{~h}$ of precipitation reaction. It indicates the presence of constituents $\mathrm{A}, \mathrm{B}, \mathrm{C}, \mathrm{D}$, and $\mathrm{E}$, according to International Center for Diffraction Data (ICDD) NO. 31088, 120056, 340917, 30598, and 511380, wherein A, B, C, D, and E show $\mathrm{CaF}_{2}, \mathrm{NaF}, \mathrm{CaCl}_{2}, \mathrm{Na}$ and $\mathrm{SiO}_{2}$, respectively. However, the presence of $\mathrm{SiO}_{2}$ may arise as impurity due to air or dust contamination. The second spectrum, from the bottom, demonstrates XRD patterns for precipitation of $\mathrm{CaF}_{2}$ when polymer K-702 with $5 \mathrm{mg} / \mathrm{L}$ is used, indicating the presence of constituents A, B, and C. According to ICDD NO. 441938, 411907, and 441588, the $\mathrm{A}, \mathrm{B}$, and $\mathrm{C}$, were assigned to $\mathrm{C}_{6} \mathrm{H}_{16} \mathrm{~N}_{2} \mathrm{O}_{4}, \mathrm{C}_{33} \mathrm{H}_{62} \mathrm{O}_{6}$, and $\mathrm{C}_{5} \mathrm{H}_{11} \mathrm{NO}_{2}$, $\left(\mathrm{CH}_{2}\right)_{2}(\mathrm{COOH})_{2}$, respectively.

Similarly, the XRD patterns for precipitation of $\mathrm{CaF}_{2}$, when $5 \mathrm{mg} / \mathrm{L}$ each of the polymer K732 and biocide sodium hypochlorite are used, showing the presence of constituents A, B, C, and D; according to ICDD NO. 401630, 381855, 321956, and 472214, in which A, B, C, and D, indicate $\mathrm{C}_{5} \mathrm{H}_{10} \mathrm{O}_{5}, \mathrm{C}_{6} \mathrm{H}_{5} \mathrm{NO}_{2}, \mathrm{C}_{3} \mathrm{H}_{6} \mathrm{O}_{3}$, and $\left(\mathrm{C}_{28} \mathrm{H}_{28} \mathrm{Cl}_{2} \mathrm{~N}_{4} \mathrm{O}_{4}\right)_{\mathrm{n}}$, respectively. The fourth spectrum, from the bottom side, represents the XRD patterns for precipitation behavior of $\mathrm{CaF}_{2}$ in the presence of $10 \mathrm{mg} / \mathrm{L}$ polymer K-732 and gluteraldehyde each. This spectrum shows the occurrence of constituents A, B, C, and D; and according to ICDD NO: 441938, 211638, 30328, and 391843 the $\mathrm{A}, \mathrm{B}, \mathrm{C}$, and $\mathrm{D}$ represent $\mathrm{C}_{10} \mathrm{H}_{20} \mathrm{~N}_{2} \mathrm{O}_{8}, \mathrm{C}_{2} \mathrm{H}_{6} \mathrm{O}_{2} \mathrm{~S}, \mathrm{CH}_{4}$ and $\mathrm{C}_{6} \mathrm{H}_{12} \mathrm{~N}_{4}$, respectively. Likewise, the XRD patterns for precipitation of $\mathrm{CaF}_{2}$ in the presence of $10 \mathrm{mg} / \mathrm{L}$ polymer $\mathrm{K}-752$ plus zero biocide. It indicates the presence of constituents $\mathrm{A}, \mathrm{B}, \mathrm{C}$, and $\mathrm{D}$, according to ICDD NO: 522057, 211638, 331804, and 130709, where A, B, C, and D indicates $\mathrm{C}_{62} \mathrm{H}_{2} \mathrm{Cl}_{6}, \mathrm{C}_{2} \mathrm{H}_{6} \mathrm{O}_{2} \mathrm{~S}$, $\mathrm{C}_{9} \mathrm{H}_{10} \mathrm{~N}_{2} \mathrm{O}_{2}$, and $\mathrm{C}_{12} \mathrm{H}_{18} \mathrm{O}_{2}$, respectively. Further, the XRD spectrum for $\mathrm{CaF}_{2}$ precipitate when $5 \mathrm{mg} / \mathrm{L}$ of polymer K-752 together with gluteraldehyde was used is shown in the topmost spectrum. The spectrum indicates the presence of $\mathrm{C}_{8} \mathrm{H}_{8} \mathrm{O}_{3}, \mathrm{C}_{10} \mathrm{H}_{16} \quad \mathrm{~N}_{4} \mathrm{O}_{6}, \mathrm{C}_{5} \mathrm{H}_{11} \mathrm{NO}_{2}$, $\left(\mathrm{CH}_{2}\right)_{2} .(\mathrm{COOH})_{2}$, and $\mathrm{C}_{8} \mathrm{H}_{8} \mathrm{~N}_{2} \mathrm{OS}$, respectively. These species corresponding to various peaks position were assigned ICDD NO: (A) 321750, (B) 482324, (C) 441588, and (D) 221548, respectively. 


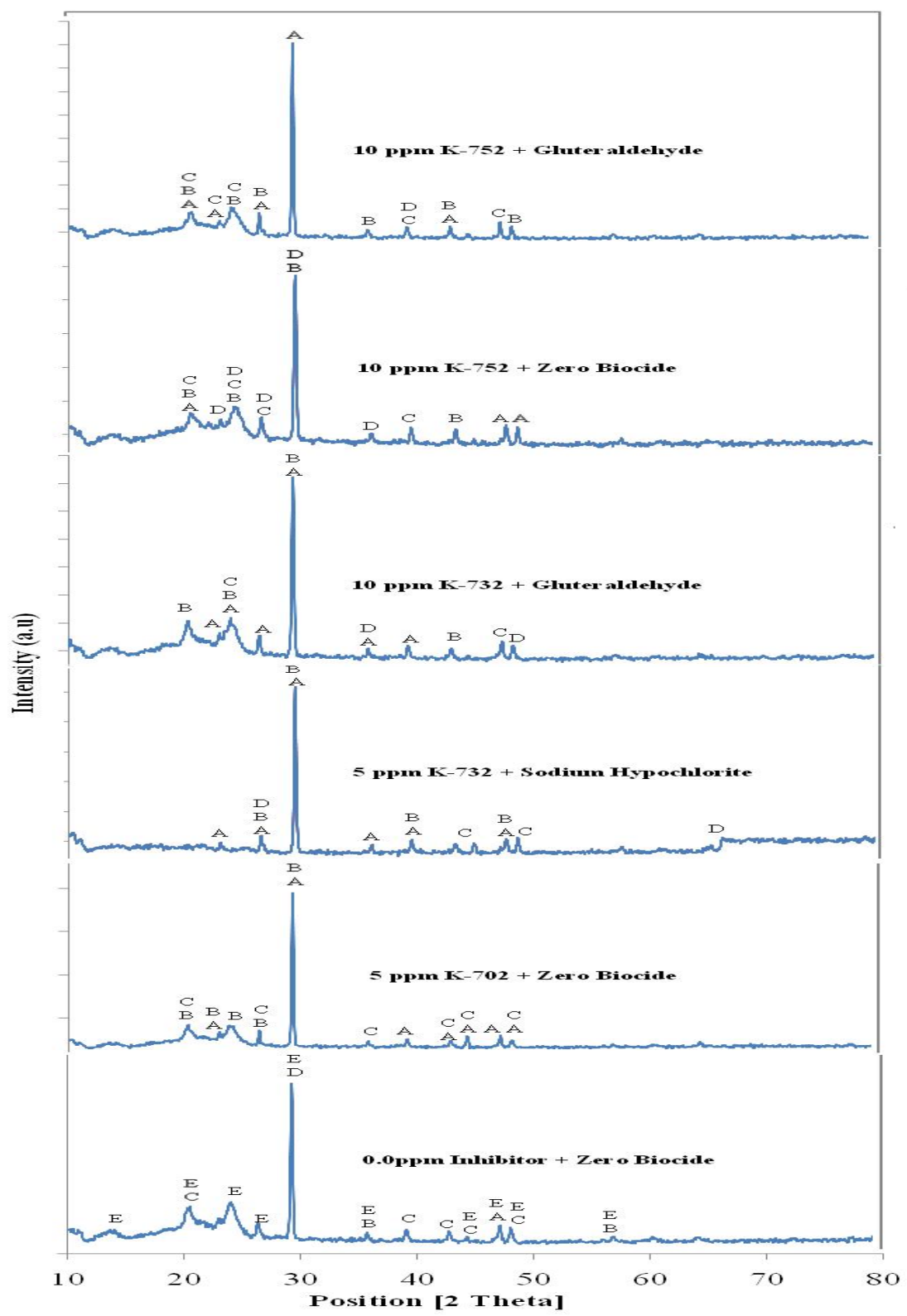

Figure 8. XRD patterns of $\mathrm{CaF}_{2}$ precipitate in the presence of polymeric inhibitors and biocides.

\section{CONCLUSION}

The effect of anionic homopolymeric inhibitors in the absence and presence of both oxidizing and non-oxidizing biocides on precipitation behaviour of calcium fluoride has been studied in 
detail. It was seen that these homopolymers $(\mathrm{K}-702, \mathrm{~K}-732$ and $\mathrm{K}-752)$ greatly inhibit the $\mathrm{CaF}_{2}$ precipitation processes, as the life time in each case is increased. In addition, it can also be said that the use of anionic homopolymeric inhibitors prominently affect the growth rate and morphology of the $\mathrm{CaF}_{2}$ precipitate, and the nature of the hydrated phase as well. It has been shown that the presence of low levels $(1 \mathrm{mg} / \mathrm{L}$ to $10 \mathrm{mg} / \mathrm{L})$ of anionic homopolymers influences $\mathrm{CaF}_{2}$ precipitation and the overall efficiency of these ionic polymeric inhibitors enhanced with changing their amount in the precipitation medium. Likewise, the chemical nature of the inhibitor also plays a promising role in the precipitation inhibition. Keeping this in mind, we are of the view that both $\mathrm{K}-702$ and $\mathrm{K}-732$ are poor $\mathrm{CaF}_{2}$ (precipitation) inhibitors as compared to $\mathrm{K}-752$ which showed better results. On the average, the inhibition power may follow the order $\mathrm{K}-752>\mathrm{K}-732>\mathrm{K}-702$. This can be attributed to the effect of molecular weight of the polymer. Higher is the molecular weight of polymer lower is its inhibiting ability. It was also found that the oxidizing as well as the non-oxidizing biocides such as sodium hypochlorite, gluteraldehyde, and tris(hydroxymethyl)nitromethane, respectively showed petty effect on the performance of these anionic homopolymeric inhibitors. The present work provides useful information on the precipitation inhibition of calcium fluoride under different water composition commonly in many industrial water systems, and also to effectively control the formation of calcium fluoride as scales and oral care application.

\section{REFERENCES}

1. McKeever, S.W.S.; Brown, M.D.; Abbundi, R.J.; Chan, H.; Mathur, V.K. Characterization of optically active sites in $\mathrm{CaF}_{2}: \mathrm{Ce}, \mathrm{Mn}$ from optical spectra. J. Appl. Phys. 1986, 60, 25052510 .

2. Chauhan, S.M.; Chakrabarty, B.S. Synthesis, characterization and optical properties of $\mathrm{CaF}_{2}$ and $\mathrm{Pb}$ doped $\mathrm{CaF}_{2}$ nanocrystals. Int. J. Eng. Res. Technol. 2014, 3, 129-131.

3. Amjad, Z. Performance of inhibitors in calcium fluoride crystal growth inhibition. Langmuir 1989, 5, 1222-1225.

4. Amjad, Z.; Pugh, J.; Zibrida, J.; Zuhl, R.W. Polymer performance in cooling water: The influence of process variables. Mater. Perform. 1997, 36, 32-38.

5. Shyu, L.J. The solid/solution interface - A kinetic study of the crystallization of calcium fluoride and phosphate. PhD Thesis, State University of New York at Buffalo, New York, 1982.

6. Vogel, G.L.; Zhang, Z.; Chow, L.C.; Schumacher, G.E.; Banting, D. Effect of in vitro acidification on plaque fluid composition with and without a $\mathrm{NaF}$ or a controlled-release fluoride rinse. J. Dent. Res. 2000, 79, 983-990.

7. Rizkallas, E.N. Kinetics of the crystallisation of barium sulphate. effect of additives, stirring rate and barium:sulphate ratio on the rate of precipitation. J. Chem. Soc. Faraday Trans. 1983, 79, 1857-1867.

8. Varsanik, R.G. Nature and control of calcium orthophosphate deposition in cooling water systems. Mater. Perform. 1975, 14, 16-22.

9. Amjad, Z. Constant composition study of the crystal growth of dicalcium phosphate dehydrate. The influence of polyphosphates, phosphonates, and phytate. Can. J. Chem. 1988, 66, 2181-2187.

10. Amjad, Z. The influence of polyphosphates, phosphonates, and poly(carboxylic acids) on the crystal growth of hydroxyapatite. Langmuir 1987, 3, 1063-1069.

11. Shimelis, B.; Zewge, F.; Chandravanshi. B.S. Removal of excess fluoride from water by aluminum hydroxide. Bull. Chem. Soc. Ethiop. 2006, 20, 17-34.

12. Fomon, S.J.; Ekstrand, J.; Ziegler, E.E. Fluoride intake and prevalence of dental fluorosis: Trends in fluoride intake with special attention to infants. J. Public Health Dent. 2000, 60, 131-139. 
13. Shah, M.T.; Danishwar, S. Potential fluoride contamination in the drinking water of Naranji area, North West Frontier Province, Pakistan. Environ. Geochem. Health 2003, 25, 475-481.

14. Warren, J.J.; Levy, S.M. Current and future role of fluoride in nutrition. Dent. Clin. North. Am. 2003, 47, 225-243.

15. Khan, A.A.; Whelton, H.O.; Mullane, D. A map of natural fluoride in drinking water in Pakistan. Int. Dent. J. 2002, 52, 291-297.

16. Khan, A.A.; Whelton H.O; Mullane, D. Determining the optimal concentration of fluoride in drinking water in Pakistan. Community Dent. Oral Epidemiol. 2004, 32, 166-172.

17. Adeno, F.; Mulugeta, E.; Zewge, F.; Chebude, Y. Adsorptive removal of fluoride from water using nanoscale aluminium oxide hydroxide (ALOOH). Bull. Chem. Soc. Ethiop. 2014, 28, 215-227.

18. Rosmalen, V.G.M.; Bennema, P. Characterization of additive performance on crystallization: Habit modification. Cryst. Growth Des. 1990, 99, 1053-1060.

19. Koutsoukos, P.G.; Amjad, Z.; Naucollas, G.H. The influence of phytate and phosphonate on the crystal growth of fluorapatite and hydroxyapatite. J. Colloid. Interface Sci. 1981, 83, 599-605.

20. Dalas, E.; Kallitsis, J.; Koutsoukos, P.G. The growth of sparingly soluble salts on polymeric substrates. Colloids Surf. 1991, 53, 197-208.

21. Zuhl, R.W.; Amjad, Z. Scale Control Polymers for Industrial Water Systems: The Science and Technology of Industrial Water Systems, CRC Press: Florida; 2010.

22. Shyu, L.; Nancollas, G.H. The kinetics of crystallization of calcium fluoride: A new constant composition method. Croat. Chem. Acta 1980, 53, 281-289.

23. Rahman, A.A.; Salem, M.; Nancollas, G.H. Mineral Scale Formation and Inhibition, Plenum Press: New York; 1995; pp 121-129.

24. Amjad, Z. Influence of calcium fluoride crystal growth by polyelectrolytes. Langmuir 1991, 7, 2405-2408.

25. Amjad, Z. Performance of inhibitor in calcium fluoride crystal growth inhibition. Langmuir 1993, 9, 597-600.

26. Maniatis, C.; Dalas, E.; Zafiropoulos, T.; Koutsoukos, P.G. Effect of various bis(sulfonamides) on the crystal growth of hydroxyapatite. Langmuir 1991, 7, 1542-1545.

27. Amjad, Z. Constant composition study of crystal growth of calcium fluoride. Langmuir 1991, 7, 600-603.

28. Amjad, Z.; Hooley, J.H. Influence of polyelectrolyte on the crystal growth of calcium sulfate dihydrate. J. Colloid Interface Sci. 1986, 111, 496-503.

29. Amjad, Z.; Koutsoukos, P.G. Mineral Scales and Deposits: An Overview, in the Science and Technology of Industrial Water Treatment, IWA Publ. and CRC Press: New York; 2010.

30. Amjad, Z.; Zuhl, R.W. Factors influencing the precipitation of calcium-inhibitor salts in industrial water systems. Association of Water Technologies (AWT-2003), Annual Convention, September 17-20, 2003, Phoenix, AZ.

31. Klepetsanis, P.G.; Kladi, A.; Koutsoukos, P.G.; Amjad, Z. The interaction of water soluble polymers with solid substrates: Implications on the kinetics of crystal growth. Prog. Colloid. Polym. Sci. 2000, 115, 106-111.

32. Amjad, Z.; Zuhl, R.W.; Zibrida, J.F. The effects of biocides on deposit control polymers. $12^{\text {th }}$ Annual Convention \& Exposition 31 October to 4 November 2000, Hawaii; Association of Water Technologies (AWT-2000), Inc.: The Hilton Hawaiian Village, Honolulu; 2000. 